\title{
Platelet concentrates: reducing the risk of transfusion-transmitted bacterial infections
}

This article was published in the following Dove Press journal:

International Journal of Clinical Transfusion Medicine

26 June 2014

Number of times this article has been viewed

\author{
Dirk de Korte' \\ Jan $\mathrm{H}$ Marcelis $^{2}$ \\ 'Department of Product and Process \\ Development, Sanquin Blood \\ Bank, Amsterdam, ${ }^{2}$ Department of \\ Microbiology, St Elisabeth Hospital, \\ Tilburg, the Netherlands
}

\begin{abstract}
The introduction of a combination of interventions during collection of whole-blood or platelet concentrates has been successful in lowering the degree of bacterial contamination in the final product, the platelet concentrate, by $50 \%-75 \%$. These interventions were improved donor questionnaires, best-practice skin disinfection, and diversion of first blood volume. These interventions have reduced the number of bacteria present in the platelet concentrates. In combination with screening for bacterial contamination of platelet concentrates with a culture method, the degree of transfusion-transmitted bacterial infection has been reduced significantly. Due to the very low initial bacteria counts upon collection of the products, the need for improved sensitivity of early screenings tests or highly selective point-of-issue tests remains. The latter should be rapid and easy to perform. An alternative approach might be the implementation of pathogen-inactivation methods for cellular blood products to reduce the amount of pathogens. However, these methods are costly, and so far not proved to be cost-effective, especially in countries with an already-low incidence of transfusion-transmitted infections by viruses, parasites, or bacteria.
\end{abstract}

Keywords: blood products, bacterial contamination, screening, point of issue, pathogen inactivation

\section{Introduction}

Transfusion-transmitted bacterial infection (TTBI) has been a serious complication of transfusion since the start of blood banking at the beginning of the twentieth century. By introduction of donor-arm disinfection and by sterilization of materials and reagents, significant improvement was achieved. The introduction of closed systems for blood collection, component preparation, and storage was a further step in reducing the frequency of TTBI. During the 1970s, the focus moved from TTBI to viral transmissions, especially as a result of the acquired immunodeficiency-syndrome epidemic, caused by human immunodeficiency virus (HIV). In the last decade of the twentieth century, there were huge efforts in screening of blood products by serological methods and the introduction of nucleic acid testing. This was combined with improved donor selection for cellular products and the introduction of pathogen-reduction techniques for plasma-derived products. Altogether, this resulted in a drastic fall in the estimated frequency of infectious donations entering the blood supply. For hepatitis B, this was brought down to 1.66 per million, for hepatitis $\mathrm{C}$ to 0.80 per million, and for HIV to only 0.14 per million, as reported for the UK over the period $1996-2003 .{ }^{1}$ At the same time, people started to realize that the risk of TTBI was still high, with up to $10 \%$ of blood transfusion-associated deaths caused by TTBI, as reported by Sazama. ${ }^{2}$ Therefore,
Correspondence: Dirk de Korte

Department of Product and Process Development, Sanquin Blood Bank, I 25 Plesmanlaan, Amsterdam 1066 CX, the Netherlands

Tel $+3 \mid 205123578$

Fax +3I 206178080

Email d.dekorte@sanquin.nl (c) (i) (\$) 2014 de Korte and Marcelis. This work is published by Dove Medical Press Limited, and licensed under Creative Commons Attribution - Non Commercial (unported, v3.0) License. The full terms of the License are available at http://creativecommons.org/licenses/by-nc/3.0/. Non-commercial uses of the work are permitted 列 Limited. Information on how to request permission may be found at: http://www.dovepress.com/permissions.php 
more attention was given to bacterial contamination as the major adverse effect of transfusion. Twenty years later, the risk of TTBI is now much lower than it was before, but still TTBI is responsible for about one fatality and multiple severe complications per 1-2 million platelet transfusions. This review describes the interventions that have led to the rapid decrease of TTBI to the current level, and the remaining risk for TTBI.

\section{Donor bacteremia}

The major source of bacterial contamination in blood products is the donor arm, ${ }^{3,4}$ and to a much lesser extent donor bacteremia, ${ }^{5}$ contaminated collection equipment, ${ }^{6}$ contamination of the blood (product) during processing, ${ }^{7,8}$ and finally procedures around transfusion in the hospital.

In the majority of cases, bacteremic donors will be too sick to attend for donation and will not show up. However, bacteremia can be asymptomatic during the incubation period of an infection and in low-grade chronic infections or can be transient, eg, after dental procedures. ${ }^{9,10}$

Yersinia enterocolitica is one of the most important microorganisms in asymptomatic donors as the result of a low-grade gastrointestinal infection. Indeed, it was reported by Tipple et $\mathrm{al}^{11}$ that half of the Yersinia cases reported were asymptomatic. Transfusion of red cells contaminated with $Y$. enterocolitica after long storage is most risky, as this microorganism is one of the few human pathogens that can grow at $4^{\circ} \mathrm{C}$ (psychrophilic). Stenhouse and Milner ${ }^{12}$ demonstrated that upon inoculation of low numbers of $Y$. enterocolitica into a fresh unit of whole blood, counts of $5 \times 10^{6} / \mathrm{mL}$ were achieved after 21 days of incubation at $4^{\circ} \mathrm{C}$. After an initial 4-day lag phase, growth proceeded briskly throughout the duration of storage at $4^{\circ} \mathrm{C}$. A recent review by Guinet et $\mathrm{al}^{13}$ found 55 reported cases of Yersinia over the period 1975-2007, with an overall fatality of 55\%. Important to note is that Yersinia is a siderophilic (iron-loving) strain of bacteria. From a review of transfusion-associated cases with Yersinia, only non-siderophore-producing serogroups have been recovered from transfused and recipient blood. ${ }^{14}$ These results suggest that upon lysis of aged erythrocytes, iron stores are liberated, which enhance $Y$. enterocolitica growth. For platelet concentrates, contamination with $Y$. enterocolitica does not seem to be a problem, with only one case reported in contrast to 54 cases related to erythrocyte transfusions. This might be related to the siderophilic character of Yersinia. After a peak in the mid-1990s, ${ }^{15,16}$ the incidence of transfusion-associated Yersinia infections seems diminished, probably related to the increased use of leukocyte-depleted blood products. ${ }^{13}$ Leukocyte removal is thought to remove Yersinia internalized but not yet killed by phagocytes, before disintegration of these phagocytes and subsequent release of viable Yersinia in the blood product during further storage.

Many other microorganisms have been described to be involved in asymptomatic bacteremia. Among them, Gram-negative bacteria usually elicit the most severe septic reactions in the recipient. This is due to the presence of lipopolysaccharides or endotoxin, a major cell-wall component in all Gram-negative bacteria that retains its toxicity even in killed bacteria. ${ }^{17} \mathrm{~A}$ well-known case of a Salmonella enterica-transfusion transmission to two patients (one of whom died) was due to asymptomatic infection of the donor with this organism from his pet boa constrictor. ${ }^{18}$

It is believed that predonation questionnaires scrutinized by skilled personnel can reveal hidden donor bacteremia, eg, to ask adequate follow-up questions if the donor reports some minor health problems. However, there are no publications to support this assumption, except for some cases with syphilis or after dental procedures. ${ }^{9}$ A case of Staphylococcus aureus contamination of platelets may have been due to bacteremia in the donor, who had undergone a tooth repair 2 hours prior to donation. ${ }^{7}$ Also the use of electric toothbrushes has been shown to significantly increase the rate of bacteremia in comparison with manual brushing, ${ }^{9,19}$ but this effect is only transient for a couple of hours.

In sum, a well-defined predonation questionnaire will help to prevent some donors with hidden bacteremia from donating. However, based on current literature data, it is not expected that changes in predonation questionnaires will add significantly to this prevention.

\section{Disinfection methods}

Commensal (resident) skin flora, mainly composed of coagulase-negative staphylococci, corynebacteria, and propionibacteria, are the most commonly detected organisms on the donor's arm. ${ }^{20}$ Incidentally, a wide spectrum of pathogenic bacteria, such as Bacilli species and Enterobacteriaceae, temporarily present on the skin (transient flora), has been detected in blood products, as reported in screening studies. ${ }^{21-23}$ In total, skin-derived organisms (resident and transient) account for over $90 \%$ of reported platelet concentrate- and $70 \%$ of reported erythrocyte concentrate-associated bacterial transmissions. ${ }^{24-26}$

Therefore, effective disinfection of the skin will result in reduction of bioburden during skin penetration upon venipuncture. Several factors affect the efficacy of skin disinfection, 
including the type and concentration of antiseptic used, the mode of application (scrub, swab, applicator, or ampoule), whether a single- or two-step method is used, the time that the antiseptic is in contact with the skin, and the training of the personnel applying the disinfectant. Formerly, optimal skin disinfection was associated with the use of multiple antiseptic agents in a two-step protocol that involved a sponge scrub to clean followed by fluid from an ampoule to kill remaining organisms. ${ }^{27}$ In 1999, an initial study on the effectiveness of donor arm-disinfection techniques was undertaken by the National Health Service Blood and Transplant in the UK to find a best practice. McDonald et $\mathrm{al}^{28}$ compared six methods, and found a two-stage process with an initial application of isopropyl alcohol followed by tincture of iodine to produce the best arm disinfection.

However, upon use in the field, this best-practice procedure caused too much waiting time (2-minute procedure), ${ }^{29}$ and thus the search continued. A single-step procedure of isopropyl alcohol with chlorhexidine was found to be a very efficacious disinfectant, but at first the volume needed was too high for comfortable use, as the donor arm remained wet too long. In a study with different volumes of $70 \%$ isopropyl alcohol $/ 2 \%$ chlorhexidine, McDonald ${ }^{30}$ showed that the volume could be reduced to $1.5 \mathrm{~mL}$ and still be equivalent in terms of disinfection efficiency. Their final method was ChloraPrep $^{\circledR}$ (a one-step chlorhexidine and isopropyl alcohol kit, 1-minute procedure; CareFusion, San Diego, CA, USA); this was introduced as the national method of donor-arm disinfection in the UK in 2006. ${ }^{31}$ The results from McDonald et $\mathrm{al}^{31}$ were confirmed by studies from Ramirez-Arcos and Goldman $^{32}$ and Benjamin et al, ${ }^{33}$ although Ramirez-Arcos and Goldman reported that isopropyl alcohol/chlorhexidine disinfectants were even superior to two-step isopropyl alcohol and iodine. Ramirez-Arcos and Goldman ${ }^{32}$ reported no difference in efficacy between one-step and two-step procedures or between methods of application for the isopropyl alcohol/ chlorhexidine disinfectants. Following this study, ChloraPrep was successfully implemented at the Canadian Blood Service (CBS) in 2009. Benjamin et al found a single-step 2\% chlorhexidine swab disinfection technique superior to a two-step povidone-iodine, ${ }^{33}$ followed by implementation of this technique as a method of disinfection for the American Red Cross (ARC).

Despite all efforts to use a "best-practice" disinfectant procedure, the result of the disinfection depends also on the quality of the skin. Dimpled skin or skin with scars or eczema will prevent proper disinfection of the surface. It has also to be kept in mind that surface disinfection will not reach microorganisms in the deeper layers of the skin or those present as biofilms. These microorganisms can only be reduced by removal of the first blood volume, as described in the next section.

\section{Removal of first blood volume}

During the 1980s, several studies were published about bacterial contamination in blood products. The results of these studies showed a broad range for the mean contamination rate of whole blood, with very wide confidence intervals due to the low numbers included in these studies. A study by de Korte et $\mathrm{al}^{4}$ was the first with sufficient numbers to show that $0.35 \%$ (95\% confidence interval $0.27 \%-0.44 \%$ ) of wholeblood units contained enough bacteria to give a positive signal in a bacterial culture test $\left(\mathrm{BacT} /\right.$ Alert $^{\circledR}$; BioMérieux, Marcy l'Etoile, France). In this study, it was confirmed that most of the microorganisms found were most probably derived from the skin of the donor, either resident or transient. Therefore, it was already suggested by Olthuis et $\mathrm{al}^{34}$ to avoid use of the first volume of collected blood. This was based on the assumption that during venipuncture, a so-called skin plug containing bacteria was punched by the needle. ${ }^{35,36}$ If the first volume of blood, containing this skin plug with bacteria, would be removed, this would reduce the bacterial load considerably. Several studies showed that this hypothesis could be true, starting with Olthuis et al, ${ }^{34}$ reporting that if one collects two blood samples in a row, the degree of contamination in the first sample is significantly higher than in the second sample. This was confirmed by Bruneau et al. ${ }^{37}$ Also, Wagner et $\mathrm{al}^{38}$ showed in an in vitro model that removal of the first volume would reduce the degree of contamination in the subsequently collected volume. However, all these studies showed only that the first blood volume collected indeed contained the highest amount of bacteria, but did not show that the finally collected blood unit had a lower degree of bacterial contamination. The final proof that removal of the first collected volume resulted in a lower degree of bacterial contamination was published by de Korte et al..$^{39}$ In their study with culture of whole blood in the BacT/Alert, they showed that removal of the first $10 \mathrm{~mL}$ of the collected blood unit into a waste tube reduced the number of positive cultures by $40 \%$. The difference was statistically significant $(P<0.05)$ for the total contamination rate, and for staphylococcal species the reduction was most strikingly from 0.14 to $0.03 \%(P<0.02)$.

The same group subsequently showed that by incorporating a small pouch with a Y-piece into the collection line of standard blood-collection systems, the diverted volume could be collected in a closed system and used for testing 
purposes. ${ }^{23}$ In this study, it was also shown that the frequency of bacterial contamination for platelet concentrates prepared from buffy coats could be reduced by more than $50 \%$ (from $0.85 \%$ to $0.37 \%$ ) by the introduction of a blood-collection system with a diversion pouch. These results were confirmed by many other groups, ${ }^{21,29,40,41}$ and since then the use of a diversion pouch in blood collection, either whole blood or apheresis, has become the standard procedure. An additional advantage of using an integrated diversion pouch is the fact that test material will always be available, although there is a very minimal risk caused by misuse of the collection system and dilution of the diverted volume with anticoagulant, for introducing false-negative test samples, as described by Nightingale et al. ${ }^{42}$

Taken together, the introduction and use of the integrated diversion pouch to remove the first blood volume from the donation has played a major role in risk reduction for TTBI, although this intervention has no effect on bacteria already in the bloodstream of the donor.

\section{Screening for bacterial contamination \\ General}

Of all blood products, platelet concentrates are most prone to be the source of TTBI, as these products are stored at room temperature, under aerated conditions with high concentrations of glucose and other nutrients for bacteria. Therefore, to reduce TTBI, screening of platelet concentrates for the presence of bacteria is most effective. For platelet concentrates derived from whole blood, this is indirectly also a screening of red blood cells, for those whole-blood units that are used to produce both products. In the Netherlands, in the case of a positive signal in a platelet-concentrate sample, related red blood cells are recalled and also tested. In the Netherlands, over the years it was found that for $97 \%$ of positive platelet concentrates, the related red blood cells were still in stock at the blood bank or hospital, and with very rare cases of already transfused red cells related to a positive platelet concentrate. ${ }^{23}$ In about $30 \%$ of positive screening results for a platelet concentrate, one of the related red blood cell units was found positive, and in $90 \%$ the same microorganism was found in platelets and red cells.

\section{Early testing}

For early testing, culture methods are the most sensitive, and as such, the method of choice, despite the disadvantage of being time-consuming and sometimes yielding irreproducible positive results. The most frequently used culture method for blood products is the BacT/Alert culture system. Depending on the degree of standardization of the process of inoculation and sample placing in the BacT/Alert incubator, this system can have a relatively high degree of false-positive results, ie, no microorganism can be isolated from a positively flagged culture bottle. With a high degree of standardization and strict temperature control during sample placing in the incubator, these kinds of false positives can be reduced to a minimum (unpublished results, Sanquin Blood Bank). In the literature, false-positive units are often divided into two groups, one due to machine failure, in which no microorganism can be cultured from the positively flagged bottle, and one as so-called unconfirmed positives, in which the positive test could not be confirmed in a second culture from the platelet product and was considered as contaminated during inoculation. This number of unconfirmed positives, labeled as false positives, is very high in some studies, depending on the type of microorganism isolated. It is unlikely that the inoculation process, under aseptic conditions, results in such a high number of false positives. ${ }^{4}$ Most probably, for most of these types of false positives, the microorganism detected in the screening did not survive in the platelet concentrate, resulting in a negative culture after second sampling. It is questionable whether these initially positive cultures that are not reproducible with repeated sampling should really be judged as false positives.

The time needed to detect bacteria is often mentioned as a disadvantage, as in early culture testing the moment of flagging positive is often after the investigated product has been transfused. ${ }^{43}$ In the Netherlands, a look-back procedure is initiated for all products released as "negative to date" with a positive culture after the unit had already been transfused. Koopman et $\mathrm{al}^{44}$ reported no cases of TTBI after such products were transfused for the period 2006-2007, a result that was confirmed in the following years (personal communication, Dr R Koopman, Sanquin Blood Bank). Similar results were obtained in Germany by Walther-Wenke et al, ${ }^{3}$ who concluded that reported transfusion reactions upon transfusion of culture-positive units (after transfusion) were not attributed to the transfusion. Fortunately, for most of the bacteria related to bacterial transmissions with high clinical impact, like Gram-negative bacteria, Bacillus cereus, and Staphylococcus aureus, the cultures flag positive within the first 24-48 hours of culture. ${ }^{23}$ Early culture testing resulted in a 50\%-75\% decrease in septic transfusion reactions (STRs), especially those due to Gram-negative bacterial contamination, which historically had accounted for approximately 
two-thirds of transfusion fatalities associated with platelet units contaminated by bacteria. ${ }^{30}$

Despite the use of early testing, some platelet concentrates remain contaminated with bacteria and sometimes result in STRs in recipients. This is due to false-negative testing results, as the actual degree of contamination might be below the sensitivity of the culture system used. For most bacteria species, it was shown that 1-10 colony forming units (CFU)/mL (with $4 \mathrm{~mL}$ inoculation) resulted in a positive culture in the BacT/Alert. ${ }^{45-47}$ By mathematical modeling, the real number of bacteria upon collection in contaminated units is thought to be between 5 and 62 CFU per unit, ${ }^{48}$ or even lower, as recently reported by Benjamin et al. ${ }^{49}$ During the rest period between collection and inoculation, this number will increase. By using a higher inoculation volume (about 8 $\mathrm{mL}$ in most studies) and/or two test bottles, sensitivity can be improved. However, because in studies in which two bottles were inoculated, the frequency of double positives was very low, ${ }^{22,23}$ it is generally accepted that the average contamination is around the detection limit of the BacT/Alert culture system, making false negatives inevitable. For several bacterial species (Staphylococcus epidermidis, Streptococcus pyogenes, Klebsiella pneumonia, and Escherichia coli), Stormer et al ${ }^{50}$ showed that with a spiking of $\sim 10 \mathrm{CFU}$ per unit of platelets (actually $0.01-0.23 \mathrm{CFU} / \mathrm{mL}$ ), the bacteria were able to grow to very high levels in platelet concentrates during storage.

\section{Rapid, late testing}

An alternative to early testing might be to test just before issuing the products to the recipients, in the blood bank or even at the bedside. If bacteria are present in the product, these can grow from the expected low initial level to easily detectable levels during storage of platelet concentrates at room temperature. Late testing can also be allowed to be less sensitive, as the level of bacteria shown to be harmful to patients is around $10^{3} \mathrm{CFU} / \mathrm{mL}$ or higher. However, this depends very much on the bacteria species and the condition of the patient receiving the transfusion. Jacobs et $\mathrm{al}^{51}$ showed that platelet units with bacteria concentrations of $<10^{5} \mathrm{CFU} /$ $\mathrm{mL}$ are much less likely to cause severe STRs than units with higher bacteria concentrations. However, units with a low bacteria concentration might still be responsible for STRs at a later moment, especially for patients with vascular implants. Bacteria can form biofilms on these devices, which are less accessible to antibiotic treatment. ${ }^{52}$

For rapid testing, two companies developed an immunoassay, and both assays are currently licensed in the US for secondary screening of platelets. These are the Pan Genera
Detection (PGD) test from Verax Biomedical (Marlborough, MA, USA) $)^{53}$ and the BacTx ${ }^{\circledR}$ from Immunetics Inc. (Boston, MA, USA). ${ }^{54}$ A substantial number of bacteria-contaminated units was found when the Verax test was used as a secondary detection assay. In a large multisite study with this test ${ }^{53}$ on the day of issue applied to apheresis units released as culture-negative, one in 3,000 units was found to be repeatedly positive and verified by confirmatory culture. Based on these results, Jacobs et $\mathrm{a}^{53}$ claimed that the implementation of rapid screening at the point of issue for apheresis platelets that tested negative by early culturing could prevent over 300 STRs per year. It is unclear whether point-of-issue screening could replace early culture testing.

In a smaller study by Dunbar et al, ${ }^{55}$ no confirmed positives were detected in 3,505 4-day-old apheresis platelet units with the Verax test. Sensitivity for Gram-positive organisms was about $10^{4}-10^{5} \mathrm{CFU} / \mathrm{mL}$ for most Gram-positive species, but detection of some strains of Gram-negative organisms (eg, E. coli and K. pneumoniae) was less sensitive. Also significant interoperator variability was reported, especially in weak-positive reactions. ${ }^{56} \mathrm{~A}$ serious problem with the use of the Verax test is the rather high false-positive rates, which range from $0.3 \%-0.5 \%$. This is of particular concern with respect to the risk-benefit analysis of special platelet products, eg, human leukocyte antigen-matched platelets. ${ }^{53,55}$ A second generation of the Verax test was recently introduced that should have a lower false-positive rate.

Alternative methods for rapid testing are flow cytometrybased methods, nucleic acid testing (polymerase chain reaction [PCR] $),{ }^{57,58}$ and delayed sampling before culturing in BacT/Alert. Sireis et al ${ }^{59}$ compared these different methods to select the best for extending the shelf life from 4 to 5 days. Standard flow cytometry did not meet the criteria for sensitivity, and although BacT/Alert was able to meet these criteria, the 12 hours needed for this method was thought to take too much time off from the additional day of shelf life that could be gained. The flow-cytometry method described by Vollmer et al, ${ }^{60}$ called BactiFlow ${ }^{\circledR}$ (BioMérieux), was found to be sensitive enough and took about 2-3 hours. Also, 16S deoxyribonucleic acid testing with PCR was found to be sensitive enough for late testing. ${ }^{59,61}$ Vollmer et $\mathrm{al}^{62}$ showed also that BactiFlow and 21S RNA reverse-transcription PCR were sensitive enough to be used for late testing.

\section{Remaining risk after introduction of screening}

A large multicenter US study (PASSPORT [Post Approval Surveillance Study of Platelet Outcomes - Release Tested]) 
indicated that of 7-day-old platelets (outdated), one in 1,500 units was contaminated with bacteria that were not detected by early automated culturing. ${ }^{63}$ Studies conducted in Ireland, Wales, and the Netherlands yielded similar results for outdated products (5-7 days) for either buffy coat-derived or apheresis products, ${ }^{48,64,65}$ whereas RamirezArcos et al published a frequency of one false negative in 4,000 outdated buffy coat-derived platelet concentrates. ${ }^{66}$ Altogether, this would mean a relatively high chance for a false-negative result, but it has to be kept in mind that only a limited number of bacterially contaminated products will result in TTBI. ${ }^{51,67}$

Based on clinical data in the US, the STR rate following transfusion of whole blood-derived platelets screened for bacteria from 2007-2011 was estimated to be one in 100,000

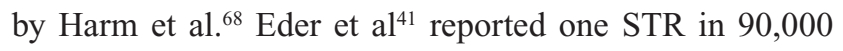
apheresis units, based on a large ARC database over the period 2006-2008 after the introduction of diversion, compared to one STR in 60,000 units before the introduction of diversion. All these clinical cases were due to false-negative results during initial screening, which is performed by the ARC with one BacT/Alert aerobic culture bottle per unit. Based on the period 2006-2011, the same group reported in $2014^{49}$ this number to be one STR in 106,000 units (with one in 1,015,000 fatalities), showing further improvement. Compared with the initial rate of one STR in 40,000 units (with one in 240,000 fatalities) before the introduction of screening and diversion, ${ }^{21}$ the overall improvement is significant, with a factor 2.5-fold reduction in STRs and a fourfold reduction in fatalities.

This improvement over the years is also reflected in the number of fatalities reported each fiscal year to the US Food and Drug Administration, as can be found on their website (http://www.fda.gov/biologicsbloodvaccines/ safetyavailability/reportaproblem/transfusiondonationfatali-

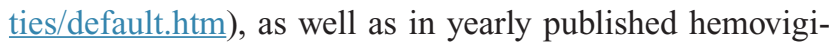
lance reports from Europe, eg, England (http://www.shotuk. org) and the Netherlands (http://www.tripnet.nl/pages/en). This improvement might be a combined result of increased awareness, implementation of improved disinfection methods (eg, ChloraPrep in the UK, ${ }^{31} \mathrm{CBS}^{32}$ and $\mathrm{ARC}^{33}$ ) and/or increased volume inoculated in BacT/Alert. ${ }^{41}$ The majority of STRs in the US seem to be caused by aerobic Gram-positive species. ${ }^{49,69}$

\section{Pathogen inactivation}

A very effective measure to reduce viral load in plasmaderived products like albumin and factor VIII concentrates was the introduction of pathogen inactivation or removal steps in the production process. These techniques were mainly focused on viruses, either well-known viruses like HIV and hepatitis $\mathrm{C}$ or new viruses thought to threaten the blood supply. Well-known examples of the latter are chikungunya ${ }^{70}$ and dengue virus, ${ }^{71}$ but many other viruses, often without a disease caused by the virus, have been repeatedly mentioned in this respect. ${ }^{72-74}$ Due to the nature of the methods in use for plasma products, like pasteurization, ${ }^{75}$ solvent-detergent treatment, ${ }^{70}$ freeze-drying ${ }^{76}$ and nanofiltration, ${ }^{77,78}$ these methods cannot be applied to cellular products.

It took some time before pathogen-inactivation methods to produce pathogen-reduced cellular products were developed. Although erythrocytes and platelets have the advantage that no nucleus is present, and thus nucleic acids can be the target for killing pathogens, the margin between doing harm to the viruses without damaging the blood cells is small. As a result of the current high level of safety with respect to viral transmission by blood products and major concerns about bacteria, especially in platelet concentrates, the focus for application of pathogen inactivation for cellular products has moved from viruses to bacteria. The risk for TTBI with severe morbidity and/or mortality is much higher than the risk for a transfusion-transmitted viral infection. This is still true after a fourfold reduction after the introduction of improved donor-arm disinfection, diversion of first collected blood volume, and screening for bacterial contamination.

So far, the available methods for pathogen reduction, currently restricted to platelet concentrates and plasma, have been shown to be very effective in killing most bacteria species. ${ }^{79}$ The bacteria species tested were selected from reports about clinical cases of TTBI and from screening results, and as such are representative for the type of microorganisms present in platelet concentrates. However, there are some limitations to these techniques. ${ }^{80,81}$ Spores from bacteria like Bacillus cereus and Clostridium perfringens are not killed at all and will remain a risk. Also, as each pathogen reduction technique is a disinfecting technique with variable decimal reduction for distinct microorganisms, high numbers of bacteria cannot be removed completely. The current methods for pathogen inactivation have a negative effect on the quality of platelets, although this is not always reflected in clinical effectiveness. ${ }^{82-86}$ In addition, introduction of these techniques is very costly, and for the Netherlands has been judged as not cost-effective. ${ }^{87}$ It has to be kept in mind that this is partly influenced by the already-high level of safety with respect to pathogen transmission by transfusion in this and many other countries, and depending on the epidemiology 
for various pathogens, the result of such exercises might differ by country.

\section{Other aspects \\ Storage-time reduction}

Fresher units have a lower risk for STRs than units stored for up to 5 days, ${ }^{21}$ with a clear increase in risk from day 3 of storage and most fatalities related to units stored for 5 days. In Germany, $80 \%$ of fatalities after TTBI due to platelet transfusion were from units stored for 5 days. ${ }^{61}$ Therefore, the authorities (Paul Ehrlich Institute) in Germany reduced storage time from 5 to 4 days. Only with additional bacterial screening on day 3 or 4 , or after implementation of pathogen reduction, could shelf life be extended back to 5 days. ${ }^{59}$ Although Jacobs et al ${ }^{53}$ did not demonstrate definitive differences in the degree of bacterial contamination between day 3 and days $4-5$, Harm et $\mathrm{a}^{68}$ showed the median age of the individual whole blood-platelet units in the contaminated pools to be 5 days (range 3-5 days) versus 4 days (range 1-5 days) in false-positive whole blood-platelet pools $(P=0.0012)$.

Therefore, an option to decrease STRs could be to screen platelets with an early culture method and to transfuse platelets as early as possible in their shelf life. For units stored longer than 4 days, a late and rapid testing should be implemented to reduce the risk that highly contaminated units would be transfused. This approach is currently used in Ireland ${ }^{65}$ and Germany ${ }^{59}$ (although in Germany without initial screening).

\section{Difference between apheresis and pooled platelets}

Before the introduction of diversion of first volume of blood, the risk of bacterial contamination for pooled buffy coat-derived platelet concentrates was clearly higher than that of apheresis products, as reported by de Korte et al. ${ }^{23}$ After implementation of diversion for all collections, this difference disappeared. ${ }^{23}$ Also, Schrezenmeier et al ${ }^{88}$ demonstrated no significant differences in risk between pooled or apheresis platelets in the German situation. This was recently confirmed by Andreu et al for the French situation. ${ }^{89}$ Lastly, a meta-analysis compared the occurrence of bacterial contamination of platelet-rich plasma (PRP)derived and buffy coat-derived platelet concentrates versus the risk of apheresis platelet concentrates. ${ }^{90}$ The risk was modeled assuming that both PRP- and buffy coat-derived concentrates were obtained from five donations, and indicated that PRP-derived platelet concentrates carried around a fivefold-higher risk of bacterial contamination than single-donor apheresis platelets, but that buffy coat-derived platelet concentrates showed no increased risk. Two of the three publications used as sources for the meta-analysis described leukoreduced PRP-derived platelet concentrates, rendering leukoreduction a less likely explanation for the observed difference. An alternative explanation might be that PRP-derived platelet concentrates are from whole blood held for at most 8 hours (as required in the US), while the publications cited for buffy coat-derived platelets all had an overnight holding time for the buffy coat (one publication) or for the whole blood (three publications). This longer holding time would allow leukocytes to phagocytose bacteria, which are subsequently removed together during the platelet concentrate preparation.

\section{Disclosure}

The authors report no conflicts of interest in this work.

\section{References}

1. Soldan K, Davison K, Dow B. Estimates of the frequency of HBV, HCV, and HIV infectious donations entering the blood supply in the United Kingdom, 1996 to 2003. Euro Surveill. 2005;10:17-19.

2. Sazama K. Reports on 355 transfusion-associated deaths: 1976 through 1985. Transfusion. 1990;30:583-590.

3. Walther-Wenke G, Schrezenmeier H, Deitenbeck R, et al. Screening of platelet concentrates for bacterial contamination: spectrum of bacteria detected, proportion of transfused units, and clinical follow-up. Ann Hematol. 2010;89:83-91.

4. de Korte D, Marcelis JH, Soeterboek AM. Determination of the degree of bacterial contamination of whole-blood collections using an automated microbe-detection system. Transfusion. 2001;41:815-818.

5. Rhame FS, Root RK, MacLowry JD, Dadisman TA, Bennett JV. Salmonella septicemia from platelet transfusions. Study of an outbreak traced to a hematogenous carrier of Salmonella cholerae-suis. Ann Intern Med. 1973;78:633-641.

6. Heltberg O, Skov F, Gerner-Smidt P, et al. Nosocomial epidemic of Serratia marcescens septicemia ascribed to contaminated blood transfusion bags. Transfusion. 1993;33:221-227.

7. Goldman M, Blajchman MA. Blood product-associated bacterial sepsis Transfus Med Rev. 1991;5:73-83.

8. Bland LA, Villarino ME, Arduino MJ, et al. Bacteriologic and endotoxin analysis of salvaged blood used in autologous transfusions during cardiac operations. J Thorac Cardiovasc Surg. 1992;103:582-588.

9. Ness PM, Perkins HA. Transient bacteremia after dental procedures and other minor manipulations. Transfusion. 1980;20:82-85.

10. Hockett RN, Loesche WJ, Sodeman TM. Bacteraemia in asymptomatic human subjects. Arch Oral Biol. 1977;22:91-98.

11. Tipple MA, Bland LA, Murphy JJ, et al. Sepsis associated with transfusion of red cells contaminated with Yersinia enterocolitica. Transfusion 1990;30:207-213.

12. Stenhouse MA, Milner LV. Yersinia enterocolitica. A hazard in blood transfusion. Transfusion. 1982;22:396-398.

13. Guinet F, Carniel E, Leclercq A. Transfusion-transmitted Yersinia enterocolitica sepsis. Clin Infect Dis. 2011;53:583-591.

14. Bottone EJ. Yersinia enterocolitica: the charisma continues. Clin Microbiol Rev. 1997;10:257-276.

15. Prentice M. Transfusing Yersinia enterocolitica. BMJ. 1992;305: 663-664. 
16. [No authors listed]. From the Centers for Disease Control and Prevention. Red blood cell transfusions contaminated with Yersinia enterocolitica - United States, 1991-1996, and initiation of a national study to detect bacteria-associated transfusion reactions. JAMA. 1997;278:196-197.

17. Martich GD, Boujoukos AJ, Suffredini AF. Response of man to endotoxin. Immunobiology. 1993;187:403-416.

18. Jafari M, Forsberg J, Gilcher RO, et al. Salmonella sepsis caused by a platelet transfusion from a donor with a pet snake. $N$ Engl $J$ Med. 2002;347:1075-1078.

19. Bhanji S, Williams B, Sheller B, Elwood T, Mancl L. Transient bacteremia induced by toothbrushing: a comparison of the Sonicare toothbrush with a conventional toothbrush. Pediatr Dent. 2002;24: 295-299.

20. Maibach H, Aly R. Skin Microbiology: Relevance to Clinical Infection. New York: Springer; 1981.

21. Eder AF, Kennedy JM, Dy BA, et al. Bacterial screening of apheresis platelets and the residual risk of septic transfusion reactions: the American Red Cross experience (2004-2006). Transfusion. 2007;47:1134-1142.

22. Munksgaard L, Albjerg L, Lillevang ST, Gahrn-Hansen B, Georgsen J. Detection of bacterial contamination of platelet components: six years' experience with the BacT/ALERT system. Transfusion. 2004;44: $1166-1173$

23. de Korte D, Curvers J, de Kort W, et al. Effects of skin disinfection method, deviation bag and bacterial screening on clinical safety of platelet transfusions in the Netherlands. Transfusion. 2006;46:476-485.

24. Perez P, Salmi LR, Follea G, et al. Determinants of transfusionassociated bacterial contamination: results of the French BACTHEM Case-Control Study. Transfusion. 2001;41:862-872.

25. Roth VR, Kuehnert MJ, Haley NR, et al. Evaluation of a reporting system for bacterial contamination of blood components in the United States. Transfusion. 2001;41:1486-1492.

26. Walther-Wenke G, Wirsing von Konig CH, Däubener W, et al. Monitoring bacterial contamination of blood components in Germany: effect of contamination reduction measures. Vox Sang. 2011;100:359-366.

27. Goldman M, Lee JH, Blajchman MA. Skin antisepsis and initial aliquot diversion. In: Brecher MA, editor. Bacterial and Parasitic Contamination of Blood Components. Bethesda (MD): AABB; 2003:31-56.

28. McDonald CP, Lowe P, Roy A, et al. Evaluation of donor arm disinfection techniques. Vox Sang. 2001;80:135-141.

29. McDonald CP, Roy A, Mahajan P, Smith R, Charlett A, Barbara JA. Relative values of the interventions of diversion and improved donorarm disinfection to reduce the bacterial risk from blood transfusion. Vox Sang. 2004;86:178-182.

30. McDonald CP. Interventions implemented to reduce the risk of transmission of bacteria by transfusion in the English National Blood Service. Transfus Med Hemother. 2011;38:255-258.

31. McDonald C, McGuane S, Thomas J, et al. A novel rapid and effective donor arm disinfection method. Transfusion. 2010;50:53-58.

32. Ramirez-Arcos S, Goldman M. Skin disinfection methods: prospective evaluation and postimplementation results. Transfusion. 2010;50:59-64

33. Benjamin RJ, Dy B, Warren R, Lischka M, Eder AF. Skin disinfection with a single-step $2 \%$ chlorhexidine swab is more effective than a twostep povidone-iodine method in preventing bacterial contamination of apheresis platelets. Transfusion. 2011;51:531-538.

34. Olthuis H, Puylaert C, Verhagen C, Valk L. Method for removal of contaminating bacteria during venapuncture [abstract]. Poster presented at: Fifth Regional Congress of the International Society of Blood Transfusion; July 2-5, 1995; Venice.

35. Gibson AP, Norris W. Skin fragments removed by injection needles. Lancet. 1958;2:983-985.

36. Blajchman MA. Bacterial contamination and proliferation during the storage of cellular blood products. Vox Sang. 1998;74S:155-159.

37. Bruneau C, Perez P, Chassaigne M, et al. Efficacy of a new collection procedure for preventing bacterial contamination of whole-blood donations. Transfusion. 2001;41:74-81.
38. Wagner SJ, Robinette D, Friedman LI, Miripol J. Diversion of initial blood flow to prevent whole-blood contamination by skin surface bacteria: an in vitro model. Transfusion. 2000;40:335-338.

39. de Korte D, Marcelis JH, Verhoeven AJ, Soeterboek AM. Diversion of first blood volume results in a reduction of bacterial contamination for whole-blood collections. Vox Sang. 2002;83:13-16.

40. Benjamin RJ, Kline L, Dy BA, et al. Bacterial contamination of whole-blood-derived platelets: the introduction of sample diversion and prestorage pooling with culture testing in the American Red Cross. Transfusion. 2008;48:2348-2355.

41. Eder AF, Kennedy JM, Dy BA, et al. Limiting and detecting bacterial contamination of apheresis platelets: inlet-line diversion and increased culture volume improve component safety. Transfusion. 2009;49: 1554-1563.

42. Nightingale MJ, Beard MJ, Bennett J, Hambleton R, Ramskill S, Thomas S. The donor line break cannula: effect on the donation process, blood component quality and transfusion microbiology testing of an important new blood bag safety feature. Transfus Med. 2013;23:219-225.

43. te Boekhorst TA, Beckers EA, Vos M, Vermeij H, van Rhenen DJ. Clinical significance of bacteriologic screening in platelet concentrates. Transfusion. 2005;45:514-519.

44. Koopman MM, van't Ende E, Lieshout-Krikke R, Marcelis J, Smid WM, de Korte D. Bacterial screening of platelet concentrates: results of 2 years active surveillance of transfused positive cultured units released as negative to date. Vox Sang. 2009;97:355-357.

45. Brecher ME, Heath DG, Hay SN, Rothenberg SJ, Stutzman LC. Evaluation of a new generation of culture bottle using an automated bacterial culture system for detecting nine common contaminating organisms found in platelet components. Transfusion. 2002;42:774-779.

46. Brecher ME, Means N, Jere CS, Heath DG, Rothenberg SJ, Stutzman LC. Evaluation of an automated culture system for detecting bacterial contamination of platelets: an analysis with 15 contaminating organisms. Transfusion. 2001;41:477-482.

47. Brecher ME, Hay SN, Rothenberg SJ. Validation of BacT/ALERT plastic culture bottles for use in testing of whole-blood-derived leukoreduced platelet-rich-plasma-derived platelets. Transfusion. 2004;44: 1174-1178.

48. Pearce S, Rowe GP, Field SP. Screening of platelets for bacterial contamination at the Welsh Blood Service. Transfus Med. 2011;21:25-32.

49. Benjamin RJ, Dy B, Perez J, Eder AF, Wagner SJ. Bacterial culture of apheresis platelets: a mathematical model of the residual rate of contamination based on unconfirmed positive results. Vox Sang. 2014;106: $23-30$.

50. Stormer M, Arroyo A, Brachert J, et al. Establishment of the first international repository for transfusion-relevant bacteria reference strains: ISBT working party transfusion-transmitted infectious diseases (WP-TTID), subgroup on bacteria. Vox Sang. 2012;102:22-31.

51. Jacobs MR, Good CE, Lazarus HM, Yomtovian RA. Relationship between bacterial load, species virulence, and transfusion reaction with transfusion of bacterially contaminated platelets. Clin Infect Dis. 2008;46:1214-1220.

52. Donlan RM, Costerton JW. Biofilms: survival mechanisms of clinically relevant microorganisms. Clin Microbiol Rev. 2002;15:167-193.

53. Jacobs MR, Smith D, Heaton WA, Zantek ND, Good CE. Detection of bacterial contamination in prestorage culture-negative apheresis platelets on day of issue with the Pan Genera Detection test. Transfusion. 2011;51:2573-2582.

54. Jacobs MR, Bajaksouzian S, Yomtovian R, et al. Detection of bacteria in leukocyte-reduced whole blood derived platelet units using the Immunetics BacTx test [abstract]. Transfusion. 2010;50S:194A.

55. Dunbar NM, Kreuter JD, Marx-Wood CR, Dumont LJ, Szczepiorkowski ZM. Routine bacterial screening of apheresis platelets on day 4 using a rapid test: a 4-year single-center experience. Transfusion. 2013;53:2307-2313.

56. Vollmer T, Hinse D, Schottstedt V, et al. Inter-laboratory comparison of different rapid methods for the detection of bacterial contamination in platelet concentrates. Vox Sang. 2012;103:1-9. 
57. Rood IG, Pettersson A, Savelkoul PH, de Korte D. Development of a reverse transcription-polymerase chain reaction assay for eubacterial RNA detection in platelet concentrates. Transfusion. 2010;50: $1352-1358$.

58. Rood IG, Pettersson A, Savelkoul PH, de Korte D. Performance and suitability of polymerase chain reaction for early detection of bacteria in platelet concentrates. Transfusion. 2011;51:2006-2011.

59. Sireis W, Rüster B, Daiss C, et al. Extension of platelet shelf life from 4 to 5 days by implementation of a new screening strategy in Germany. Vox Sang. 2011;101:191-199.

60. Vollmer T, Dreier J, Schottstedt V, et al. Detection of bacterial contamination in platelet concentrates by a sensitive flow cytometric assay (BactiFlow): a multicentre validation study. Transfus Med. 2012;22: 262-271.

61. Schmidt M, Sireis W, Seifried E. Implementation of bacterial detection methods into blood donor screening-overview of different technologies. Transfus Med Hemother. 2011;38:259-265.

62. Vollmer T, Kleesiek K, Dreier J. Detection of bacterial contamination in platelet concentrates using flow cytometry and real-time PCR methods. Methods Mol Biol. 2013;943:91-103.

63. Dumont LJ, Kleinman S, Murphy JR, et al. Screening of single-donor apheresis platelets for bacterial contamination: the PASSPORT study results. Transfusion. 2010;50:589-599.

64. Karssing W, de Wildt-Eggen J, van Zeelst J, et al. Frequency of falsenegative cultures in screening of platelet concentrates for bacterial contamination [abstract]. Transfusion. 2010;50S:31A.

65. Murphy WG, Foley M, Doherty C, et al. Screening platelet concentrates for bacterial contamination: low numbers of bacteria and slow growth in contaminated units mandate an alternative approach to product safety. Vox Sang. 2008;95:13-19.

66. Ramirez-Arcos S, Kou Y, Mastronardi C, Perkins H, Goldman M. Bacterial screening of outdated buffy coat platelet pools using a culture system and a rapid immunoassay. Transfusion. 2011;51:2566-2572.

67. de Korte D. Implementation of a screening system for bacteria detection. In: Brecher MA, editor. Bacterial and Parasitic Contamination of Blood Components. Bethesda (MD): AABB; 2003;85-107.

68. Harm SK, Delaney M, Charapata M, Aubuchon JP, Triulzi DJ, Yazer MH. Routine use of a rapid test to detect bacteria at the time of issue for nonleukoreduced, whole blood-derived platelets. Transfusion 2013;53:843-850

69. Palavecino EL, Yomtovian RA, Jacobs MR. Detecting bacterial contamination in platelet products. Clin Lab. 2006;52:443-456.

70. Leydold SM, Farcet MR, Kindermann J, et al. Chikungunya virus and the safety of plasma products. Transfusion. 2012;52:2122-2130.

71. Stramer SL, Linnen JM, Carrick JM, et al. Dengue viremia in blood donors identified by RNA and detection of dengue transfusion transmission during the 2007 dengue outbreak in Puerto Rico. Transfusion. 2012;52:1657-1666.

72. Schmidt M, Geilenkeuser WJ, Sireis W, Seifried E, Hourfar K. Emerging pathogens - how safe is blood? Transfus Med Hemother. 2014;41:10-17.

73. Alter HJ, Stramer SL, Dodd RY. Emerging infectious diseases that threaten the blood supply. Semin Hematol. 2007;44:32-41.

74. Stramer SL, Hollinger FB, Katz LM, et al. Emerging infectious disease agents and their potential threat to transfusion safety. Transfusion. 2009;49 Suppl 2:1S-29S.
75. Klamroth R, Gottstein S, Orlovic M, Heinrichs C. Long-term efficacy and safety of a pasteurized, plasma-derived factor VIII concentrate (Beriate P) in patients with haemophilia A. Thromb Res. Epub November 17, 2013.

76. Unger U, Poelsler G, Modrof J, Kreil TR. Virus inactivation during the freeze-drying processes as used for the manufacture of plasma-derived medicinal products. Transfusion. 2009;49:1924-1930.

77. Caballero S, Diez JM, Belda FJ, et al. Robustness of nanofiltration for increasing the viral safety margin of biological products. Biologicals. 2014;42:79-85.

78. Hofstra JJ, Kleine BI, van Twuywer E, et al. Treatment of hereditary angioedema with nanofiltered $\mathrm{C} 1$-esterase inhibitor concentrate $\left(\right.$ Cetor $\left.^{\circledR}\right)$ : multi-center phase II and III studies to assess pharmacokinetics, clinical efficacy and safety. Clin Immunol. 2012;142:280-290.

79. Prowse CV. Component pathogen inactivation: a critical review. Vox Sang. 2013;104:183-199.

80. Schmidt M, Kapzrak B, Pfeiffer HU, Henschler R, Sireis W, Seifried E. Efficiency of pathogen inactivation system INTERCEPT under experimental conditions [abstract]. Vox Sang. 2011;101 Suppl 1: 226-227.

81. Goodrich RP, Gilmour D, Hovenga N, Keil SD. A laboratory comparison of pathogen reduction technology treatment and culture of platelet products for addressing bacterial contamination concerns. Transfusion . 2009;49:1205-1216

82. Kerkhoffs JL, van Putten WL, Novotny VM, et al. Clinical effectiveness of leucoreduced, pooled donor platelet concentrates, stored in plasma or additive solution with and without pathogen reduction. Br J Haematol. 2010;150:209-217.

83. van der Meer PF, Kerkhoffs JL, Curvers J, et al. In vitro comparison of platelet storage in plasma and in four platelet additive solutions, and the effect of pathogen reduction: a proposal for an in vitro rating system. Vox Sang. 2010;98:517-524.

84. Schubert P, Coupland D, Culibrk B, Goodrich RP, Devine DV. Riboflavin and ultraviolet light treatment of platelets triggers p38MAPK signaling: inhibition significantly improves in vitro platelet quality after pathogen reduction treatment. Transfusion. 2013;53:3164-3173.

85. Cookson P, Thomas S, Marschner S, Goodrich R, Cardigan R. In vitro quality of single-donor platelets treated with riboflavin and ultraviolet light and stored in platelet storage medium for up to 8 days. Transfusion. 2012;52:983-994.

86. Cid J, Escolar G, Lozano M. Therapeutic efficacy of platelet components treated with amotosalen and ultraviolet A pathogen inactivation method: results of a meta-analysis of randomized controlled trials. Vox Sang. 2012;103:322-330.

87. Janssen MP, van der Poel CL, Buskens E, Bonneux L, Bonsel GJ, van Hout BA. Costs and benefits of bacterial culturing and pathogen reduction in the Netherlands. Transfusion. 2006;46:956-965.

88. Schrezenmeier H, Walther-Wenke G, Müller TH, et al. Bacterial contamination of platelet concentrates: results of a prospective multicenter study comparing pooled whole blood-derived platelets and apheresis platelets. Transfusion. 2007;47:644-652.

89. Andreu G, Vasse J, Sandid I, Tardivel R, Semana G. Use of random versus apheresis platelet concentrates. Transfus Clin Biol. 2007;14:514-521.

90. Vamvakas EC. Relative safety of pooled whole blood-derived versus single-donor (apheresis) platelets in the United States: a systematic review of disparate risks. Transfusion. 2009;49:2743-2758.
International Journal of Clinical Transfusion Medicine

\section{Publish your work in this journal}

International Journal of Clinical Transfusion Medicine is an international, peer-reviewed, open access, online journal publishing clinicalexperimental, policy-making and evidence-based practices of all topics pertaining to clinical transfusion medicine. Original research, short reports, reviews, case reports and commentaries are invited.

\section{Dovepress}

The manuscript management system is completely online and includes a very quick and fair peer-review system, which is all easy to use. Visit http://www.dovepress.com/testimonials.php to read real quotes from published authors. 